\title{
Prevention and Early Detection of Urologic Cancers: A Mini-Review
}

\section{Aoun Fouad ${ }^{1,2 *}$ and Alexandre Peltier ${ }^{1,2}$}

${ }^{1}$ Department of Urology, Jules Bordet Institute, 1 Rue Héger-Bordet, 1000 Brussels, Belgium

${ }^{2}$ Université Libre de Bruxelles, 50 Franklin Roosevelt Avenue, 1050 Brussels, Belgium

\begin{abstract}
Urological cancers are among the commonest cancers in western countries. Progress in the domain of prevention and early detection of cancer is well known by researchers but studies have shown that advices for patients are sparse, inconsistent and even contradictory. The possible beneficial effects for prevention and early detection of urologic cancers are addressed in this mini-review. Emphasis will be placed on the role of alcohol and tobacco use, natural compounds, dietary supplements, early detection and pharmacological therapy on the risk of each urologic cancer. Most evidence suggests that alcoholic beverages contain a variety of carcinogenic contaminants that are introduced during fermentation and production. Many chemicals are present in tobacco smoke, including at least 69 known carcinogens. Smokeless tobacco, chewing tobacco and dipping snuff contains at least 28 carcinogens. Calorie restricted diet is associated with improvement of urologic cancer outcomes. Obesity is an established risk factor for kidney and prostate cancer. There is an association between obesity and cancer-specific mortality in bladder cancer. There is limited evidence indicating no association between physical activity and testicular or bladder cancers but a growing body of research suggests a modest risk reduction for kidney cancer and advanced prostate cancer. It seems to be no effect of lycopen and carbohydrates with prostate cancer chemoprevention. In addition, there is little evidence to support daily use of multivitamins to protect against urologic cancers. The tremendous potential benefits of catechins in tea, pomegranate, luteolin and flavanoid, needs further studies to confirm their role in urologic cancers chemoprevention. For medical agents, statins and 5 alpha reductases inhibitors are good candidates for future studies. Screening is not recommended for all urologic cancers except for prostate cancer where controversies remain. In contrast, opportunistic screening leads to early detection and decrease specific cancer mortality for almost all urologic cancers.
\end{abstract}

Keywords: Urologic cancers; Prevention; Screening; Early detection

\section{Introduction}

Cancer has overtaken cardiovascular disease to become the leading cause of death among men and women younger than 85 years in the United States, and the number of cancer deaths continues to increase [1]. Urological cancers (prostate, bladder, kidney and testicular) are among the commonest cancers in western countries. They affect both men and women, although more common in men. They account for one in three of all cancers in men, and one in five of all cancers in the general population [2].

In many respects, cancer could be considered as a preventable disease. Estimates indicate that approximately half of the cancers occurring today either arise from modifiable risk factors or can be detected as precursor lesions before the development of disease with metastatic potential [1]. In addition, about one-third of cancers in high-income Western countries are attributable to factors relating to food, nutrition, and physical activity [3]. Although diet, obesity, and physical inactivity are modifiable causes of cancer, it is challenging to identify with confidence specific associations between these factors and cancer over a lifetime, because of the long latent period for cancer development and its complex pathogenesis.

Prevention of cancer can take place on several different levels: primary prevention addresses the cause of cancer to protect healthy people from developing it, secondary prevention identifies disease in its earliest stages to slow its progression, and tertiary prevention reduces complications of disease to maximize quality of life. In most cases, a combination of primary, secondary and tertiary interventions are needed to achieve a meaningful degree of prevention and protection.

Although progress in the domain of prevention of cancer is well known by researchers, studies have shown that advices for patients are sparse, inconsistent and even contradictory. Very few top cancer centers provide online specific recommendations about cancer prevention. Moreover, practitioners are facing an increase demand from the patients for nutritional recommendations before and especially after treatment of cancer.
For urological cancers, the problem is more profound. Finding an association between common dietary regimen or natural compounds or common prescribed medication in elderly and prostate cancer which is a common disease in elderly is difficult. In addition, assessing the association of risk factors with less common cancers like kidney and testicular cancer is more challenging and evidence base is more limited. Another difficulty stems from the long latency period for urologic cancers which makes epidemiological studies and surveys difficult to realize.

In clinical practice, assessment of an individual's risk is a key step in urologic cancer prevention; Review of personal and family medical history, work history, and lifestyle can help identify cancer risk factors, which may be modifiable or nonmodifiable. Combinations of these risk factors place some people at particularly high risk. In this minireview, we address the possible beneficial effects studied for prevention of urologic cancers. Emphasis will be placed on the role of alcohol and tobacco use, natural compounds, dietary supplements, early detection and pharmacological therapy on the risk of each urologic cancer.

\section{Lifestyle and Dietary Factors}

\section{Alcohol}

Alcohol is a common term for ethanol or ethyl alcohol, a chemical substance found in alcoholic drinks as well as in some medicines,

*Corresponding author: Aoun Fouad, Department of Urology, Jules Bordet Institute, 1 Rue Héger-Bordet, 1000 Brussels, Belgium, Tel: 003-225-413-125; E-mail: fouad.aoun@bordet.be

Received February 25, 2014; Accepted May 07, 2014; Published May 09, 2014

Citation: Fouad A, Peltier A (2014) Prevention and Early Detection of Urologic Cancers: A Mini-Review. Med chem S1: 006. doi:10.4172/2161-0444.S1-006

Copyright: $\odot 2014$ Fouad A, et al. This is an open-access article distributed under the terms of the Creative Commons Attribution License, which permits unrestricted use, distribution, and reproduction in any medium, provided the original author and source are credited. 
mouthwashes, household products, and essential oils. Alcohol is produced by the fermentation of sugars and starches by yeast. Alcoholic drinks contain different percentages of ethanol, but in general a standard size drink of any type-12 ounces of beer, 5 ounces of wine, or 1.5 ounces of 80 -proof liquor contains about the same amount of ethanol (about half an ounce). There is some evidence in the literature suggesting that the amount of alcohol consumed over time and not the type of alcoholic beverage is the most important factor in raising cancer risk [4].

Most evidence suggests that alcoholic beverages contain a variety of carcinogenic contaminants that are introduced during fermentation and production, such as nitrosamines, asbestos fibres, phenols, and hydrocarbons. In addition, acetaldehyde, a metabolite of ethanol is a well established toxic chemical. By damaging DNA and proteins, it is incriminated by researchers to be a probable human carcinogen. Ethanol may also generate reactive oxygen species which can damage DNA and proteins. Another mechanism of carcinogenesis could be by interfering with the absorption of a variety of nutrients known to influence the process of carcinogenesis [5].

In their meta-analysis, Song et al. found that alcoholic beverage intake was inversely associated with a lower risk of renal cell cancer, with moderate consumption conferring the protection and higher consumption conferring no additional benefits [6]. The association was found in each sub group (wine, beer, whiskey). For testicular and prostate cancers, numerous studies have examined their association with alcohol consumption. For these cancers, either no association with alcohol use had been found or the evidence for an association was inconsistent $[7,8]$. However for bladder cancer, there is strong evidence suggesting that alcohol consumption slightly increase the risk [9].

\section{Tobacco use}

Tobacco consumption is common, and thus its epidemiologic impact is massive. An estimated $20 \%$ of adults in the United States and Europe are current cigarette smokers. Tobacco use accounts for approximately one third of cancer deaths in the US [10]. Of these, kidney and bladder cancer mortality have also been linked to smoking [11]. Many chemicals are present in tobacco smoke, including at least 69 known carcinogens [12]. Smokeless tobacco chewing tobacco and dipping snuff contains at least 28 carcinogens [13]. Smoking may also promote more aggressive forms of cancer: for example, tobacco use was associated with higher-grade and higher-stage prostate cancer in large scale epidemiological studies $[14,15]$.

Smoking is recognized as an etiologic factor for urothelial cancer accounting for $50 \%$ of tumours [16]. Tobacco smoke contains aromatic amines, such as b-naphthylamine, and polycyclic aromatic hydrocarbons known to cause urothelial cancers. These are renally excreted and exert a carcinogenic effect on the entire urinary system. There is some evidence suggesting that pipe, cigar and environmental smoking slightly increase the risk of urothelial bladder tumour [16].

The association between renal cell cancer and cigarette smoking is also well established, although reported risk increases for ever-smokers compared with never-smokers are moderate. In a recent meta-analysis, ever-smoking produced a relative risk for renal cell cancer of 1.38 , and risk increases were generally greater among men than women [17]. There is also strong evidence suggesting that smoking cessation confers protective effects in kidney cancers [17].

If smoking is a well known risk factor for kidney and bladder cancers, its relationship with prostate cancer risk is less clear. In a recent meta-analysis, current smoking was not associated with risk of prostate cancer, but there was an increased risk among heavy smokers. However, in that study, current smoking was associated with increased prostate cancer mortality and a recent study showed that smoking at the time of diagnosis was related to a higher risk of prostate cancerspecific mortality [15].

\section{Alimentary habits and physical activity}

The assumption that calorie restricted diet is associated with improvement of cancer outcomes is corroborated by both animal experiments and epidemiological studies. Mice fed a calorie-restricted diet had significantly slower tumour growth than those fed their regular diet [18]. Multiple population-based studies of underweight patients have revealed a significantly lower cancer incidence than in the general population $[19,20]$. Furthermore, obesity was an established risk factor for kidney and prostate cancer in a comprehensive systematic review of epidemiological studies by the World Cancer Research Fund (WCRF) and American Institute for Cancer Research (AICR) [21,22]. Prospective studies have also demonstrated an association between obesity and cancer-specific mortality, in bladder cancer [23]. For physical activity, if there is convincing evidence that it protects against colon and breast cancers, association with urologic cancers is less well explored. There is limited evidence indicating no association between physical activity and testicular or bladder cancers but a growing body of research suggests a modest risk reduction for kidney cancer [24$26]$. Also, a large number $(>30)$ of studies suggests a probable small decrease in prostate cancer risk which is likely driven by the effect on advanced/aggressive tumors [26-29]. The role of physical activity in decreasing urologic cancer risk is thus likely limited to advanced prostate and possibly kidney cancers with no association in testicular or bladder cancers.

For diet and alimentary habits, evidence has also accumulated, over the last years, suggesting that by systematically reducing the amount of dietary carbohydrates (CHOs) one could suppress, or at least delay, the emergence of cancer, and that proliferation of already existing tumor cells could be slowed down [30]. This hypothesis is supported by the association between modern chronic diseases like the metabolic syndrome and the risk of developing or dying from cancer [31]. CHOs or glucose, to which more complex carbohydrates are ultimately digested, can have direct and indirect effects on tumor cell proliferation: first, contrary to normal cells, most malignant cells depend on steady glucose availability in the blood for their energy and biomass generating demands and are not able to metabolize significant amounts of fatty acids or ketone bodies due to mitochondrial dysfunction. Second, high insulin and Insulin-like Growth Factor (IGF)-1 level resulting from chronic ingestion of CHO-rich Western diet meals, can directly promote tumor cell proliferation via the insulin/IGF1 signaling pathway. Third, ketone bodies that are elevated when insulin and blood glucose levels are low, have been found to negatively affect proliferation of different malignant cells in vitro or not to be usable by tumor cells for metabolic demands, and a multitude of mouse models have shown antitumorigenic properties of very low CHO ketogenic diets [32,33]. Large observational studies suggest that high intake of refined carbohydrates may be associated with increased risk of prostate cancer [34]. However no significant associations with high-risk prostate cancer are found and not all foods that are typically high in refined carbohydrates were associated with prostate cancer [35].

Alimentary regimens rich in animal fat are known to be carcinogenic for several cancers but the evidence in urology is less clear. For kidney cancer, a pooled analysis of 13 prospective studies in 2008 found a statistically significant positive associations or trends 
in pooled age-adjusted models for intakes of total fat, saturated fat, monounsaturated fat, polyunsaturated fat, cholesterol, total protein, and animal protein. However, these associations were attenuated and no longer statistically significant after adjusting for body mass index, fruit and vegetable intake, and alcohol intake. Intakes of fat and protein or their subtypes, red meat, processed meat, poultry, and seafood were not associated with risk of renal cell cancer an there were no clear associations between intakes of coffee, tea, milk, juice, soda, punch, and water and risk of renal cell cancer. Greater total fluid intake didn't reduce the risk of renal cell cancer [36].

For bladder cancer, there is no strong evidence in the literature suggesting an association of bladder cancer with beverages of coffee, tea, milk, juice, soda, punch, and water. Like for kidney cancer, greater total fluid intake doesn't reduce the risk of bladder cancer. A diet rich in fruits was found to slightly decrease the risk of bladder cancer [37].

There are some prospective studies suggesting a positive association between prostate cancer and high intake of red meat cooked at high temperatures, pan-fried, or well-done [38]. Processed meat intake was also associated with bladder cancer in two prospective studies [39]. Summary of findings of multiple studies for each urologic cancer are shown in Tables 1,2 and 3.

\section{Chemoprevention}

Cancer chemoprevention is defined as pharmacological intervention with synthetic or naturally occurring compounds that may prevent, inhibit, or reverse carcinogenesis, or prevent the development of invasive cancer. An ideal chemopreventive agent is expected to be nontoxic, effective at low doses, orally taken, and inexpensive.

\section{Nutrients}

If epidemiologic studies have consistently found that a diet rich in fruits and vegetables is associated with reduced risk for cancer, it remains unclear whether daily multivitamins can result in a similar benefit. Multivitamin use is widespread among adults in the United States, with nearly one half of all Americans taking some form of dietary supplement and one third taking a daily multivitamin. Despite the popular belief that daily multivitamins protect against cancer, there is little evidence to support such claims in human trials. Several large-scale observational studies have found no association between multivitamin use and cancer [40,41], and some have even reported increased mortality among patients taking multivitamins $[42,43]$.

For prostate cancer, high dietary intake of zinc was associated with lower prostate cancer specific mortality after diagnosis particularly in men with localized disease in a Swedish cohort published in 2011 [44]. In vitro studies had demonstrated that Zinc-citrate compound can induce apoptotic cell death in castration resistant prostate cancer cell line, by caspase-3 activation through up-regulation of apoptotic proteins and down-regulation of antiapoptotic proteins [45]. Vitamin D3 supplementation at 4000 international units per day for one year had resulted in a decrease of positive cores at repeat biopsy in subjects with low-risk prostate cancer under active surveillance in an interventional study [46]. Several studies have shown that folate and vitamin B12 supplementation was not associated with a reduced bladder, kidney or prostate cancer risk [47-50].

As for selenium and vitamin $\mathrm{E}$, there is considerable preclinical evidence suggesting a reduction of prostate cancer risk. Three large scale epidemiological studies have examined the impact of these nutrients

\begin{tabular}{|c|c|c|c|}
\hline Evidence & Convincing* & Probable $^{\star *}$ & Possible ${ }^{* * *}$ \\
\hline Substantially increased risk & & - & - \\
\hline Moderately increased risk & First degree relatives & Intakes of fat & Surgery for Benign Prostatic Enlargment (RRx8) \\
\hline Slightly increase risk & & $\begin{array}{l}\text { Carbohydrates intake } \\
\text { Vitamine } E(400 \mathrm{UI} / \mathrm{d}) \text { Obesity } \\
\text { Milk diary }\end{array}$ & Surgery for Benign Prostatic Enlargment (RRx2) \\
\hline No association & & Selenium Lycopen & \\
\hline Slightly decreased risk & & $\begin{array}{l}\text { Zinc } \\
\text { Circumcision } \\
\text { Physical activity }\end{array}$ & Quercetin, Genistein, Resveratrol, Curcumin \\
\hline Moderately decreased risk & $\begin{array}{l}\text { Dutasteride } \\
\text { Finasteride }\end{array}$ & $\begin{array}{l}\text { Fruit and vegetable intake } \\
\text { Epigallocatechin-3-Gallate }\end{array}$ & Vitamine D \\
\hline Substantially decreased risk & - & - & - \\
\hline
\end{tabular}

Table 1 : Prostate cancer and Prevention.

\begin{tabular}{|l|l|l|l|}
\hline Evidence & Convincing & Probable \\
\hline Substantially increased risk & Cigarette smoking & - \\
\hline Moderately increased risk & - & - & - \\
\hline Slightly increase risk & Alcohol consumption for men & - \\
\hline No association & & $\begin{array}{l}\text { Pipe } \\
\text { Cigar } \\
\text { Environmental smoking }\end{array}$ \\
\hline Slightly decreased riske & - & $\begin{array}{l}\text { Coffee, Tea, Vegetable } \\
\text { Vitamin A (carotenoids) }\end{array}$ \\
\hline Moderately Decreased risk & & Vitamin C \\
\hline Substantially decreased risk & - & Fruit \\
\hline
\end{tabular}

Table 2: Bladder Cancer and Prevention. 
Citation: Fouad A, Peltier A (2014) Prevention and Early Detection of Urologic Cancers: A Mini-Review. Med chem S1: 006. doi:10.4172/2161-0444. S1-006

Page 4 of 12

\begin{tabular}{|l|l|c|}
\hline Evidence & Convincing & Probable \\
\hline Substantially increased risk & $\begin{array}{l}\text { Cigarette smoking } \\
\text { Obesity }\end{array}$ & - \\
\hline Moderately increased risk & $\begin{array}{l}\text { HTA } \\
\text { First degree relatives }\end{array}$ & - \\
\hline Slightly increase risk & - & - \\
\hline No association & $\begin{array}{l}\text { High alcoholic consumption } \\
\text { total fluid intake }\end{array}$ & $\begin{array}{l}\text { Pipe, cigar } \\
\text { Environmental smoking }\end{array}$ \\
\hline Slightly decreased riske & $\begin{array}{l}\text { Moderate alcoholic consumption (beer, } \\
\text { wine and wiskey) } \\
\text { fruit and vegetable intake }\end{array}$ & $\begin{array}{l}\text { coffee, tea, milk, juice, soda, } \\
\text { punch, water }\end{array}$ \\
\hline Moderately Decreased risk & - & - \\
\hline Substantially decreased risk & & - \\
\hline
\end{tabular}

Table 3: Kidney Cancer and Prevention.

on prostate cancer. The Alpha-Tocopherol, Beta Carotene (ATBC) trial reported a $35 \%$ risk reduction for prostate cancer in men taking $50 \mathrm{mg} / \mathrm{d}$ of vitamin $\mathrm{E}$ for a median of 6.1 years [51]. Another large prospective randomized trial that had examined the effect of these 2 agents for prostate cancer prevention was The Selenium and Vitamin E Cancer Prevention Trial (SELECT) which had randomized in 200135533 men into 4 groups: selenium with matching placebo, vitamin $\mathrm{E}$ with matching placebo, both agents, or placebo [52]. Initial data from SELECT, reported in late 2008, showed that daily selenium and vitamin in E supplements, taken either alone or together for a median of 5.5 years, did not prevent prostate cancer [52]. The data also showed two concerning trends: a small increase in the number of prostate cancer cases in men taking only vitamin $\mathrm{E}$, and a small increase in the number of cases of diabetes in men taking only selenium. Updated data from SELECT, reported in 2011, show that, after an average of 7 years $(5.5$ years on supplements and 1.5 off supplements), there were 17 percent more cases of prostate cancer in men taking only vitamin $\mathrm{E}$ than in men taking only placebos [53]. This difference, an absolute increase of 11 cases per 1,000 men, was statistically significant. The Physicians Health Study II (PHS II) conducted contemporaneously with SELECT intervention with $400 \mathrm{IU}$ of vitamin E every other day for a median of 8 years had no effect on the incidence or overall mortality of prostate cancer [54].

The increased incidence of prostate cancer seen in SELECT, the previously reported increased incidence of lung cancer with highdose beta carotene in both ATBC [51] and the Beta-Carotene and Retinol Efficacy Trial (CARET) [55], and the increased risk of colon polyps seen in a trial administering high-dose folate [56], suggest that caution should be used when recommending or studying high doses of micronutrients. As opposed to synthetic pharmaceuticals, these naturally occurring dietary constituents are part of normal physiology, and a $\mathrm{U}$-shaped-dose response curve may exist where either deficiency or supraphysiological doses are harmful. Furthermore, the fact that the increased risk of prostate cancer in the vitamin E group of participants in SELECT was only apparent after extended follow-up suggests that health effects from these agents may continue even after the intervention is stopped, emphasizing the need for long-term follow-up even in trials closed before the planned intervention period is completed.

\section{Natural compounds}

There is growing interest in medicinal botanicals as part of complementary medicine in the United States. Approximately $40 \%$ of Americans use alternative remedies, including herbal medicine, for disease prevention and therapy [57]. The high cost, side effects, and therapeutic limitations of conventional medications are key factors that are driving the revival of herbal remedies. People can easily obtain herbal medicines or botanical supplements on an over-the counter basis, and feel comfortable consuming these products, even though safety and efficacy are generally not established on a rigorous scientific basis. Moreover, dietary compounds have drawn a great deal of attention because of their safety and potential ability to reduce the risk of cancer.

\section{Tea beverages}

Next to water, tea, a complex chemical compounds made from the leaves of Camellia sinensis, an evergreen shrub of the Theaceae family, is the most popular beverage consumed in the world and is distinguished by the presence of a group of polyphenols called catechins. A growing body of evidence from laboratory animal studies demonstrates that tea consumption has an inhibitory effect on carcinogenesis at various organ sites [58]. The bioavailability and biotransformation of tea polyphenols, however, are the key factors for the abovementioned chemopreventive effects of tea against tumorigenesis $[59,60]$.

At present, epidemiological studies have not yielded conclusive evidence of the protective effect of tea consumption against the development of human cancers [61-63]. However, limited epidemiological studies suggest that people drinking more cups of tea regularly have a lower risk of prostate cancer [64].

Four major tea components epigallocatechin-3-gallate (EGCG), epigallocatechin (EGC), epicatechin-3-gallate (ECG), and epicatechin (EC), present in green, black and other teas act by inhibiting mutagenesis $[65,66]$, genotoxicity $[67,68]$, transformation [69-71], cell proliferation, [72-80] and angiogenesis [59,60]. Each mechanism involves multiple potential molecular targets. Although both black tea and green tea have been studied for their chemopreventive potential, green tea showed greater efficacy against prostate cancer probably because the concentration of EGCG is increased in green tea [74]. Studies of large populations of men have shown that those who consume green tea regularly are less likely to develop prostate cancer than men who shun the beverage [81]. In other studies, researchers found that the risk of prostate cancer decreases proportionally as the amount, frequency, and duration of green tea consumption increases [82]. In terms of amount of tea consumed, men who drank more than three cups of green tea daily showed a reduced risk of prostate cancer. In a large study that evaluated the green tea drinking habits of 49,920 men aged 40 to 69 who were followed for at least 10 years, the investigators found that men who consumed five or more cups of green tea daily had a reduced risk of advanced prostate cancer when compared with men who drank less than one cup daily [83]. 
It also appears that catechins in green tea may benefit men who have High Grade Prostatic Intraepithelial Neoplasia (HGPIN). In a 2006 a study published in Cancer Research, randomized 60 men who had high-grade PIN in a double-blind, placebo-controlled study. Men in the treatment group receiving three 200-mg capsules of catechins daily had significantly fewer cancer on the one year control biopsy compared with controls. For other urologic cancers no association was found [84].

\section{Carotenoids}

Carotenoids are pigments that give yellow, red, and orange vegetables and fruits their colors. They are known for their antioxidant activity and their potential protective role against cancer. The body uses some types of carotenoids to make vitamin A. studies of vitamin A's possible role in urologic cancer prevention have been generally disappointing. There have been no consistent findings showing, in clinical trials, lower risk of cancers of bladder, or prostate due to diet rich in vitamin A [85]. Lycopene is another carotenoid compound that gives tomatoes and certain other fruits and vegetables their color. Though not considered an essential nutrient for humans, it is one of the major carotenoids in the diet of North Americans and Europeans. People who have diets rich in tomatoes, which contain lycopen, appear in some studies to have a lower risk of certain types of cancer, especially cancers of the prostate [86-88]. This finding has piqued interested in its use for prostate cancer prevention. Studies have examined the effects of lycopene on prostatic growth. In one study, normal human prostate epithelial cells were treated with synthetic lycopen [88]. High doses of lycopen inhibited the growth of prostatic epithelial cells supporting the notion that lycopen could be used clinically. A systematic review of the literature identified eight randomized controlled trials comparing lycopen with placebo for the treatment of prostate cancer [89]. A meta-analysis did not identify a significant decrease in the incidence of prostate cancer [90]. Consequently, there is insufficient evidence for or against the use of lycopen in prostate cancer.

\section{Saw palmitto}

Saw palmetto is the common name for the plant Serenoa repens. Its putative mechanism of action may be to reduce dihydro-testosterone in prostatic tissue [91]. The use of saw palmetto for the prevention of prostate cancer was evaluated in a large epidemiologic study of 35,171 men [92]. Saw palmetto had no detectable effect on prostate cancer risk. There is currently no evidence to justify the use of saw palmetto for the prevention of prostate cancer.

\section{Pomegranate and luteolin}

The fruit of the tree Punica granatum grown mainly in the Mediterranean region, has been shown to possess many medicinal properties such as being anti-oxidant and anti-inflammatory [93]. The antioxidant activity of flavonoids obtained from pomegranate juice was observed to be close to that of green tea and significantly greater than red wine [94-96]. Malik et al. observed growth inhibition in prostate cancer cells and decreased serum level of PSA [97]. Pomegranate extract also inhibited the proliferation of Human Umbilical Vein Endothelial Cells (HUVEC) and decrease the xenografted prostate cancer size, tumor micro vessel density, Vascular Endothelial Growth Factor (VEGF) levels, and Hypoxia-Inducible Factor (HIF) [98]. Pantuck et al. found a statistically significant prolongation of PSA doubling time in patients with rising PSA and treated with 8 ounces of pomegranate juice daily until disease progression suggesting a potential role for pomegranate in prostate cancer prevention. Pomegranate consumption may retard prostate cancer progression and improve patient's quality of life [99].
Luteolin, another flavonoid found in a variety of vegetables, especially in broccoli, celery, cabbage, spinach, green pepper, and cauliflower had the same anti-oxidant and anti-inflammatory properties as pomegranate [100]. Luteolin has been found to induce cell cycle arrest and apoptosis in a variety of cancer cells including prostate cancer cells both in vitro and in vivo [101].

\section{Soy isoflavones}

Soy isoflavones include genistein, daidzein, and glycitein. Genistein is the most active and abundant isoflavone found in soybeans and soy products. It has Selective Estrogen Receptor Modulator (SERM) properties similar to tamoxifen and raloxifene [102]. Epidemiological studies show an inverse association between dietary soy consumption and the risk of prostate cancer [103]. Consumption of a soy isoflavone mixture consisting of genistein and daidzein inhibited prostate cancer cell growth in culture by inducing G2/M arrest and apoptosis, inhibited the secretion of PSA, and increased the radiation effect against prostate cancer in cell culture and in orthotopic and metastatic in vivo models $[104,105]$.On the basis of these observations, several early clinical trials either with genistein or soy products have been completed. A pilot study conducted in patients with prostate cancer and rising serum PSA levels suggested that soy isoflavones may benefit some patients with prostate cancer [106]. Another phase II trial in biochemically relapsed prostate cancer patients showed a significant decrease in the serum PSA level [107]. Moreover, soy isoflavones have shown potent anti-oxidant and anti-inflammatory properties and therefore could potentially protect normal tissues from radiation toxicity, thereby decreasing urinary, intestinal, and sexual adverse effects in patients receiving radiation therapy for prostate cancer [108-112].

\section{Pharmacological Therapy}

\section{Alpha reductases inhibitors}

Although two large randomized double-blind, placebo-controlled, multicenter trials have demonstrated that $5 a$-reductase inhibitors reduce prostate cancer risk by $20 \%$ to $25 \%[113,114]$; the use of these agents is controversial because of concerns related to an observed increased risk of high-grade disease. In the Prostate Cancer Prevention Trial (PCPT), finasteride significantly reduced by $26 \%$ the risk of prostate cancer compared to placebo. Reduction in risk was limited to Gleason score 6. However, a significant increased incidence of Gleason score 8-10 with finasteride compared to placebo ( $1.8 \%$ versus $1.1 \%$, respectively) was noted [113]. In the Reduction by Dutasteride of Prostate Cancer Events (REDUCE) study, dutasteride significantly reduced by $23 \%$ overall risk of biopsy detectable prostate cancer when compared to placebo. This overall risk reduction was limited to a decrease in Gleason score 6 and an increased incidence of Gleason score 8-10 with dutasteride versus placebo ( $1 \%$ versus $0.5 \%$, respectively) [114]. The possible induction of high-grade tumors is an area of concern with the use of 5-alpha reductase. FDA Drug Safety Communication had stated "5-alpha reductase inhibitors (5-ARIs) may increase the risk of a more serious form of prostate cancer".

A REDUCE Follow-Up Study assessed the occurrence of prostate cancer in the two years following the conclusion of the REDUCE study (REEDEM). This study shows that with 2 years further follow-up beyond the original REDUCE trial there were no Gleason 8-10 tumors diagnosed. A possible reason for this difference is that any prostate cancer that may have been suppressed by dutasteride during REDUCE was no longer being suppressed for those subjects who did not continue 5ARI therapy [115]. 
Even if PCPT and REDUCE studies showed a decrease of cancers with the use of 5 alpha-reductase (5ARI) but with side effects, there is no indication for prostate cancer prevention by these drugs. In the same way, despite the results of REEDEM study, there is no indication of these drugs in active surveillance. Committee of Cancerology of the French Association of Urology noted that no recommendation can be given for indications of 5ARI in prevention or treatment of prostate cancer.

\section{Statins}

Statin drugs are competitive inhibitors of 3-hydroxy-3methylglutaryl-coenzyme A reductase, the enzyme that controls conversion of 3-hydroxy-3-methylglutaryl-coenzyme A to mevalonate, an essential precursor of cholesterol [116].

Statins are used to treat hypercholesterolemia and have been shown to reduce cardiovascular disease incidence and mortality [117]. Thus, use of statins has increased exponentially in the United States over the last decade [118]. Numerous in vitro experimental data have shown that statins exhibit antitumor effects against various leukemia cells and solid tumor cells of different origins. These effects primarily resulted from the suppression of proliferation and the induction of apoptosis [119]. Epidemiologic studies of statin use in relation to prostate cancer risk have been inconclusive. Recent evidence, however, suggests that longer-term use may reduce risk of more advanced disease [120].

By inhibiting the synthesis of cholesterol, a precursor of androgens, statin use could have beneficial effects in prostate cancer [121]. In experimental models, statins inhibit cell proliferation, inflammation, oxidative stress, angiogenesis, and metastasis in prostate cancer cells $[122,123]$.

When interpreting studies linking statins to prostate cancer, four concepts should be kept in mind. First, different statins have different antiproliferative and proapoptotic effects on various tumor cell lines of differing origins. Second, the antitumor effects were found only when lipophilic statins (fluvastatin, lovastatin, cerivastatin, atorvastatin and simvastatin) were examined. Third statins differ significantly in their antitumor potential due to different physicochemical properties. Fourth, statin cytotoxicity may depend on the target tumour type [124].

Available evidence on bladder cancer is conflicting. The findings of a meta-analysis done by Zhang et al. suggested that there was no association between statin use and risk of bladder cancer. They concluded that more studies, especially RCTs, are needed to confirm the absence of association [125]. For kidney cancer, clinical studies have shown that statin use may modify the risk. However, these studies yielded different results. The findings of a meta-analysis done by the same authors, suggested that there was no association between statin use and risk of kidney cancer. They also concluded that more studies especially randomized controlled trials and high quality cohort studies with larger sample size, well controlled confounding factors are needed to confirm this association in the future [126]. The effects of statins on urologic cancers are described in Table 3.

\section{Biguanides}

In the 1920s, biguanides were identified as the active ingredient of Galega officinalis and in the 1950s, they were developed as therapeutics. Since then, metformin has become the drug of choice for the treatment of type 2 diabetes. In addition, metformin can inhibit cancer cell growth in vitro [127-129]. Hirsch et al. explained that metformin selectively kills cancer stem cells and blocks tumor growth [130]. They also observed a synergistic action of metformin with chemotherapeutic drugs in order to reduce tumor mass and prolongation of remission in nude mice. Meta-analyses of metformin and cancer risk in diabetic patients described around one-third reduction in overall cancer risk and cancer mortality in metformin users compared with other antidiabetic drugs $[131,132]$. However, a large multicenter study did not find an association between metformin use and risk of prostate cancer among older men with diabetes, regardless of cancer grade or method of diagnosis [133].

\section{Nonsteroidal anti-inflammatory drugs}

The rationale for using aspirin and Non-Steroidal AntiInflammatory Drugs (NSAIDs) in prostate cancer prevention stems from laboratory studies suggesting inflammation plays a role in prostate carcinogenesis [134]. Elevated levels of prostaglandin and cyclooxygenase-2 enzyme (COX-2) have been found in prostate cancer cell lines [135], and regression of HGPIN has been observed in mouse xenograft models treated with NSAIDs [136]. Several cohort studies examined the association between NSAIDs and prostate cancer risk. A meta-analysis in 2010 incorporated 24 observational studies [137]. Aspirin was associated with a $17 \%$ reduction in prostate cancer overall and a $19 \%$ reduction in advanced prostate cancer. Studies on NSAIDs without aspirin, had also demonstrated a reduced prostate cancer risk but the decrease was modest and they were not associated with reduced advanced cancer risk.

\section{Screening tests and early detection}

There are two types of screening: organised screening programmes and opportunistic screening programmes. Organised screening programmes should be of a high standard, checked and monitored by people from outside the programme. Organised screening programmes refer to universal screening, mass screening or population screening and include tests and exams used to find a cancer in the absence of any symptoms.

Opportunistic screening refers to selective screening or individual early detection and takes place when someone asks their doctor for a check or test, or when the doctor offers a check or test to people who are known to be at higher risk of developing cancer.

Screening, however, is not without harms. The extent and magnitude of harms must be considered before screening is recommended. The harms of screening are to be individualized and weighed against the risks of disease and benefits of early detection. If the relative risk for disease is greater for the individual and the relative harms of screening is reduced, then screening with early disease detection is therefore desirable. Conversely, if the risk for disease is low, then the relative harms of screening may outweigh the relative benefits, and, consequently, it would be less attractive to screen. The harms of screening may be associated with true-positive and -negative and false-positive and -negative results. The diagnosis of inconsequential true-positive diseases may lead to investigation and treatment of diseases that may or may not affect an individual's life. A true-negative result is reassuring but can incur costs during the investigative process. False-negative results are potentially dangerous because they provide false assurances, which subsequently lead to delay and misdiagnoses. False-positive findings may result in inappropriate and excessive investigations that could be harmful. Guidelines should therefore provide explicit, unbiased, and relevant evidence to inform an individual's overall risk of disease, benefits, and harms when making the eventual decisions on screening [138]. 


\section{Kidney cancer}

Kidney cancer is one of the rare cancer models explaining that screening should be individualized and weighed against the risks of disease and benefits of early detection. In the era of medical imaging, the annual incidence of renal cell carcinoma has been rising, with the greatest increase observed for cases with localized tumors [139-142]. Ablative surgery for small renal masses had paralleled their rising incidence with the assumption that early intervention will achieve netter survival outcomes $[143,144]$. However, this assumption is not supported by population-based mortality data $[139,140]$. This suggests a need for careful assessment of the benefits of screening that may lead to investigation and treatment of diseases that may or may not affect an individual's life. The significance of early detection of small renal masses is under debate that's why, in the present base of knowledge, all professional organizations recommend against kidney cancer mass screening. Opportunistic screening with annual kidney ultrasound should be offered only to high risk population: chronic kidney failure, dialysis and kidney transplants. In patients with a family history of hereditary kidney tumour, genetic counselling is advised. Depending on the histological and syndromic features, genetic testing for a particular mutation can be initiated in an affected member. In most cases, this provides presymptomatic diagnosis, or confirms the diagnosis, especially in cases in which a family mutation is already known. Mutation negative cases can be reassured that there is no significantly higher risk for renal cancer in them or their children. Mutation carriers can be entered into a screening program. Patients harbouring the same mutation should be offered kidney ultrasound every two years from the age of 30 years or 10 years before the earliest tumour was diagnosed in a family member.

\section{Testicular cancer}

There is no standard or routine screening test used for early detection of testicular cancer. Most often, testicular cancer is first found by patients themselves, either by chance or during self-exam. Sometimes the cancer is found by doctors during a routine physical exam or for unspecific scrotal complaints. No studies have been done to find out if would decrease the risk of dying from this disease. A Cochrane review identified no randomised controlled trials that have evaluated the effectiveness of testicular self-exams, regular exams by a doctor, or other screening tests in men with no symptoms on the risk of dying from the disease [145]. In the absence of any evidence from high quality randomised controlled trials, there is insufficient evidence to unequivocally support, or refute, screening for testicular cancer. The USPSTF (United States Preventive Services Task Force) recommends against routine screening for testicular cancer in asymptomatic adolescent and adult males [146]. The USPSTF based this recommendation on the relative rarity of testicular cancer, the lack of evidence showing the accuracy of clinical or self-examination, and highly favourable outcomes from treatment even with advanced disease. However, The USPSTF did not review the evidence for screening among men with at increased risk for testicular cancer. Furthermore, routine screening probably would not decrease the risk of dying from testicular cancer but finding it early may make it easier to treat. Patients who are diagnosed with testicular cancer that has not spread to other parts of the body may need less chemotherapy and surgery, resulting in fewer side effects. The ACSP states « check up for men $>20$ years should include examination for testicular cancer " and the EAU states « self physical examination is advisable for individuals with clinical risk factors » [147].

\section{Bladder cancer}

Screening test used in primary care include urine dipstick or microscopic urinalysis for hematuria, urine cytology, and tests for urine biomarkers. Positive screening results are referred to an urologist for cystoscopy and biopsy/resection, imaging, and other studies if tumour is found. Urinary cytology is convenient and detects bladder cancer with high specificity, but its diagnostic ability is rather disappointing due to its low sensitivity (40-76\%) [148]. Cystoscopy is highly invasive and relatively expensive, and thus, majority of the patients would be distressed. In clinical practice, the positive predictive value of screening is $<10 \%$ in asymptomatic persons [148]. For urine biomarkers, a number of urine-based tests have been developed. These include tests based on Bladder Tumour Antigen (BTA), Nuclear Matrix Protein 22 (NMP22), urine fibrin and Fibrinogen Degradation Products (FDP), ImmunoCyt, and FISH (UroVysion) [149-151]. However, the diagnostic capability of all of these tests is insufficient to recommend them in clinical practice. Furthermore no randomized trials or high-quality controlled observational studies had evaluated clinical outcomes associated with screening compared to no screening, or treatment of screen-detected bladder cancer compared to no treatment. In addition, no study had evaluated the sensitivity or specificity of tests for hematuria, urinary cytology, or urinary biomarkers for bladder cancer in asymptomatic persons without a prior history of bladder cancer and harms associated with treatment for screen-detected bladder cancer compared to no treatment. This explains why major organizations do not recommend screening for bladder cancer in asymptomatic adults. For example, the USPSTF in 2010 recommended against routine screening for bladder cancer in asymptomatic adults (I recommendation: insufficient data) [152]. In 2011, the American Academy of Family Physicians endorsed the U.S. Preventive Services Task Force (USPSTF) recommendation. The European Association of Urology states that the best approach to primary prevention of muscle-invasive bladder cancer is to eliminate active and passive smoking. The American Cancer Society states that prompt attention to bladder symptoms is the best approach for finding bladder cancer in its earliest, most treatable stages in persons with no known risk factors. For symptomatic adults (painless macroscopic hematuria, storage LUTS) and high risk population (smoker, occupational exposure, pelvic radiotherapy, chemotherapy) with microscopic hematuria, opportunistic screening by at least a flexible cystoscopy and cytology is mandatory.

\section{Prostate cancer}

The results of screening by PSA and DRE every year from the age of 50 years are contradictory because of cost and uncertain long-term benefits to patients. However, evidence from randomized trials on the effects of screening for prostate cancer on disease-specific mortality and screening-associated harms accumulates slowly with increasing follow-up. The European Randomized Study of Screening for Prostate Cancer (ERSPC) study documented that screening resulted in a 20 percent reduction in prostate cancer mortality [153]. Recently, the ERSPC has published its 11 years follow-up results. They demonstrated that screening does significantly reduce death from prostate cancer. The latest study confirms that a man who undergoes PSA testing will have his risk of dying from prostate cancer reduced by $29 \%$. After unblinding of the ERSPC trial results, the Swedish part of ERSPC was the first centre that published its results, showing a $44 \%$ prostate cancer mortality reduction in favour of screening with a follow-up of $14 \mathrm{yr}$ [154]. Recently, the Rotterdam centre reported a significant $32 \%$ prostate specific mortality reduction in favour of screening in men aged 55-69 $\mathrm{yr}$ at the start of the trial after a median follow-up of almost 13 years [155]. The Finnish centre reported a nonsignificant 15\% 
Citation: Fouad A, Peltier A (2014) Prevention and Early Detection of Urologic Cancers: A Mini-Review. Med chem S1: 006. doi:10.4172/2161-0444. S1-006

Page 8 of 12

\begin{tabular}{|l|l|l|}
\hline Type de cancer & Statins & Comments \\
\hline Prostate Cancer Cells & Lovastatin, fluvastatin et simvastatin & Antitumoral effect in vitro \\
\hline Prostate Cancer & $\begin{array}{l}\text { Controversy } \\
\text { (protective effect of lipophilic statins /advanced cancer?) }\end{array}$ & Clinical trials: influence of statins on the risk of cancer \\
\hline Bladder Cancer & Contradictory & Clinical trails: influence of statins on the risk of cancer \\
\hline Kidney Cancer & Protective effect of lipophilic statins & Clinical trails: influence of statins on the risk of cancer \\
\hline Prostate Cancer & Lovastatin & One Clinical trial using Lovastatin as an anticancer agent \\
\hline Prostate Cancer Cells & Celecoxib+atorvastatin & Action In vitro of statins combined with other anticancer agents \\
\hline Bladder Cancer & Sorafenib+statins & Action In vitro of statins combined with other anticancer agents \\
\hline
\end{tabular}

Table 4 : Statins and cancer: current and future prospects. Cancer lett 2012 Nov 1;324(1):1-12.

\begin{tabular}{|c|c|c|}
\hline Organization & year & Recommandations \\
\hline $\begin{array}{l}\text { European Association } \\
\text { of Urology }\end{array}$ & 2011 & $\begin{array}{l}\text { 1-Widespread screening not appropriate. } \\
\text { 2-Offer early detection to well-informed men. } \\
\text { 3-Baseline PSA at age } 40 \mathrm{yr} \text { has been suggested on which subsequent screening interval may be based. } \\
\text { 4-Screening interval of } 8 \mathrm{yr} \text { might be enough in men with initial PSA }<1 \mathrm{ng} / \mathrm{ml} \text {. } \\
5 \text {-Further PSA testing is not necessary in men }>75 \mathrm{yr} \text { of age and a baseline PSA }<3 \mathrm{ng} / \mathrm{ml}\end{array}$ \\
\hline $\begin{array}{l}\text { American Urological } \\
\text { Association }\end{array}$ & 2009 & $\begin{array}{l}\text { 1-Offer early detection to asymptomatic men }>40 \mathrm{yr} \text { of age who wish to be screened and who have an estimated life expectancy }>10 \mathrm{yr} \text {. } \\
2-\text { Screening intervals should be based on this baseline PSA level. } \\
3-\text { A ssess the individual patient's health status to determine the appropriateness of PSA testing at any given age. }\end{array}$ \\
\hline $\begin{array}{l}\text { American Cancer } \\
\text { Society }\end{array}$ & 2010 & $\begin{array}{l}\text { 1-Asymptomatic men who have at least a } 10 \text {-yr life expectancy should have an opportunity to make an informed decision with their } \\
\text { health care provider about whether to be screened. } \\
\text { 2-Men at average risk should receive this information beginning at } 50 \mathrm{yr} \text { of age. } \\
\text { 3-African American men and men who have a first-degree relative diagnosed with } \mathrm{PCa}<65 \mathrm{yr} \text { should receive this information } \\
\text { beginning at age } 45 \mathrm{yr} \text {. } \\
\text { 4-Men with multiple family members diagnosed with } \mathrm{PCa}<65 \mathrm{yr} \text { should receive this information beginning at age } 40 \mathrm{yr} \text {. }\end{array}$ \\
\hline $\begin{array}{l}\text { National Comprehensive } \\
\text { Cancer Network }\end{array}$ & 2010 & $\begin{array}{l}\text { 1-Offer baseline digital rectal examination and PSA testing at age } 40 \text { after providing counseling on the pros and cons of early } \\
\text { detection. } \\
\text { 2-If African American, if there is a family history of PCa, or if the PSA level is }>1.0 \mathrm{ng} / \mathrm{ml} \text {, repeat annually. } \\
\text { 3-Otherwise, repeat at age } 45 \text { and annually starting at } 50 \text {. Screening in men }>75 \mathrm{yr} \text { should be considered individually. }\end{array}$ \\
\hline
\end{tabular}

\section{Table 5: Recommandations.}

mortality reduction with $13 \mathrm{yr}$ of follow-up [156]. This is in contrast to the U.S. Prostate, Lung, Colorectal and Ovarian (PLCO) Cancer Screening Trial which has been unable to demonstrate any difference in prostate cancer mortality between the two arms of the study [157]. The USPSTF recommended in 2011 against PSA screening in healthy men [158]. The American Cancer Society states also that it does not support routine screening for prostate cancer because the benefits are unclear or unproven [159]. The European Association of Urology recommended to offer early detection to well informed men $[160,161]$. According to the section of Rotterdam and Goteborg in the ERSPC study, the trend actually is to have a PSA value at the age of 40 years and to recommend screening by a DRE and a PSA every two years for a high risk population. Opportunistic screening is, in contrast, offered to every patient after discussion with his physician. Summary of the recommendation of professional organizations are stated in Table 4.

\section{Conclusion}

Prevention offers the most cost-effective long-term strategy for the control of cancer. It plays a major role at various stages of carcinogenesis. For urologic cancers, avoiding all kind of smoking, moderate alcohol intake, and a safe cardiovascular regimen are beneficial. Given the tremendous potential benefits of catechins in tea, pomegranate, luteolin and flavanoid, further studies are needed especially in prostate cancer chemoprevention. It seems to be no effect of lycopen and carbohydrates with prostate cancer chemoprevention. In addition, there is little evidence to support daily use of multivitamins to protect against urologic cancers. For medical agents, statins and 5 alpha reductases inhibitors are good candidates for future studies. Screening is not recommended for all urologic cancers except for prostate cancer where controversies remain. In contrast, opportunistic screening leads to early detection and decrease specific cancer mortality for almost all urologic cancers (Table 5).

\section{References}

1. http://www.who.int/mediacentre/factsheets/fs297/en/print.html.

2. Jemal A, Siegel R, Ward E, Hao Y, Xu J, et al. (2009) Cancer statistics, 2009. CA Cancer J Clin 59: 225-249.

3. Ferlay J, Shin HR, Bray F, Forman D, Mathers C, et al. (2010) Estimates of worldwide burden of cancer in 2008: GLOBOCAN 2008. Int J Cancer 127: 2893-2917.

4. Seitz HK, Stickel F (2007) Molecular mechanisms of alcohol-mediated carcinogenesis. Nat Rev Cancer 7: 599-612.

5. Allen NE, Beral V, Casabonne D, Kan SW, Reeves GK, et al. (2009) Moderate alcohol intake and cancer incidence in women. J Natl Cancer Inst 101: 296305

6. Song DY, Song S, Song Y, Lee JE (2012) Alcohol intake and renal cell cancer risk: a meta-analysis. Br J Cancer 106: 1881-1890.

7. Shinn EH, Basen-Engquist K, Thornton B, Spiess PE, Pisters L (2007) Health behaviors and depressive symptoms in testicular cancer survivors. Urology 69 748-753.

8. Rota M, Scotti L, Turati F, Tramacere I, Islami F, et al. (2012) Alcoho consumption and prostate cancer risk: a meta-analysis of the dose-risk relation. Eur J Cancer Prev 21: 350-359.

9. Pelucchi C, La Vecchia C (2009) Alcohol, coffee, and bladder cancer risk: a review of epidemiological studies. Eur J Cancer Prev 18: 62-68.

10. (2005) Cancer Facts and Figures. American Cancer Society.

11. Sasco AJ, Secretan MB, Straif K (2004) Tobacco smoking and cancer: a brief review of recent epidemiological evidence. Lung Cancer 45 Suppl 2: S3-9.

12. IARC Working Group on the Evaluation of Carcinogenic Risks to Humans (2004) Tobacco smoke and involuntary smoking. IARC MonogrEvalCarcinog Risks Hum 83: 1-1438.

13. IARC Working Group on the Evaluation of Carcinogenic Risks to Humans (2007) Smokeless tobacco and some tobacco-specific N-nitrosamines. IARC MonogrEvalCarcinog Risks Hum 89: 1-592.

14. Giovannucci E, Rimm EB, Ascherio A, Colditz GA, Spiegelman D, et al. (1999) 
Smoking and risk of total and fatal prostate cancer in United States health professionals. Cancer Epidemiol Biomarkers Prev 8: 277-282.

15. Zu K, Giovannucci E (2009) Smoking and aggressive prostate cancer: a review of the epidemiologic evidence. Cancer Causes Control 20: 1799-1810.

16. Letašiová $S 1$, Medve'ová $A$, Šovčíková $A$, Dušinská $M$, Volkovová $K$, et al. (2012) Bladder cancer, a review of the environmental risk factors. Environ Health 11 Suppl 1: S11.

17. Hunt JD, van der Hel OL, McMillan GP, Boffetta P, Brennan P (2005) Renal cell carcinoma in relation to cigarette smoking: meta-analysis of 24 studies. Int $\mathrm{J}$ Cancer 114: 101-108

18. Champ CE, Baserga R, Mishra MV, Jin L, Sotgia F, et al. (2013) Nutrient restriction and radiation therapy for cancer treatment: when less is more. Oncologist 18: 97-103.

19. Flegal KM, Graubard BI, Williamson DF, Gail MH (2007) Cause-specific excess deaths associated with underweight, overweight, and obesity. JAMA 298: 20282037.

20. Wolin KY, Colditz GA (2008) Can weight loss prevent cancer? Br J Cancer 99: 995-999.

21. Kane CJ, Bassett WW, Sadetsky N, Silva S, Wallace K, et al. (2005) Obesity and prostate cancer clinical risk factors at presentation: data from CaPSURE. J Urol 173: 732-736.

22. Bergström A, Hsieh CC, Lindblad P, Lu CM, Cook NR, et al. (2001) Obesity and renal cell cancer--a quantitative review. $\mathrm{Br} \mathrm{J}$ Cancer 85: 984-990.

23. Qin Q, Xu X, Wang X, Zheng XY (2013) Obesity and risk of bladder cancer: a meta-analysis of cohort studies. Asian Pac J Cancer Prev 14: 3117-3121.

24. Behrens G, Leitzmann MF (2013) The association between physical activity and renal cancer: systematic review and meta-analysis. Br J Cancer 108: 798811.

25. Wolin KY, Stoll C (2012) Physical activity and urologic cancers. UrolOncol 30: 729-734.

26. Burgio KL, Newman DK, Rosenberg MT, Sampselle C (2013) Impact of behaviour and lifestyle on bladder health. Int J Clin Pract 67: 495-504.

27. Discacciati A, Wolk A (2014) Lifestyle and dietary factors in prostate cancer prevention. Recent Results Cancer Res 202: 27-37.

28. Lynch BM, Friedenreich CM, Kopciuk KA, Hollenbeck AR, Moore SC, et al. (2014) Sedentary Behavior and Prostate Cancer Risk in the NIH-AARP Die and Health Study. Cancer Epidemiol Biomarkers Prev

29. McGlynn KA, Trabert B (2012) Adolescent and adult risk factors for testicular cancer. Nat Rev Urol 9: 339-349.

30. LeRoith D (2010) Can endogenous hyperinsulinaemia explain the increased risk of cancer development and mortality in type 2 diabetes: evidence from mouse models. Diabetes Metab Res Rev 26: 599-601.

31. Seyfried TN, Shelton LM (2010) Cancer as a metabolic disease. NutrMetab (Lond) 7: 7.

32. Huang XF, Chen JZ (2009) Obesity, the PI3K/Akt signal pathway and colon cancer. Obes Rev 10: 610-616.

33. Pollak M (2008) Insulin and insulin-like growth factor signalling in neoplasia Nat Rev Cancer 8: 915-928.

34. Stattin P, Björ O, Ferrari P, Lukanova A, Lenner P, et al. (2007) Prospective study of hyperglycemia and cancer risk. Diabetes Care 30: 561-567.

35. Freedland SJ, Mavropoulos J, Wang A, Darshan M, Demark-Wahnefried W, et al. (2008) Carbohydrate restriction, prostate cancer growth, and the insulin-like growth factor axis. Prostate 68: 11-19.

36. Lee JE, Mannisto S, Spiegelman D, Hunter DJ, Bernstein L, et al. (2009) Intakes of fruit, vegetables, and carotenoids and renal cell cancer risk: a pooled analysis of 13 prospective studies. Cancer Epidemiol Biomarkers Prev 18 1730-1739.

37. Zeegers MP, Kellen E, Buntinx F, van den Brandt PA (2004) The association between smoking, beverage consumption, diet and bladder cancer: a systematic literature review. World J Urol 21: 392-401.

38. Koutros S, Cross AJ, Sandler DP, Hoppin JA, Ma X, et al. (2008) Meat and meat mutagens and risk of prostate cancer in the Agricultural Health Study. Cance Epidemiol Biomarkers Prev 17: 80-87.
39. Michaud DS, Holick CN, Giovannucci E, Stampfer MJ (2006) Meat intake and bladder cancer risk in 2 prospective cohort studies. Am J Clin Nutr 84: 1177 1183.

40. Neuhouser ML, Wassertheil-Smoller S, Thomson C, Aragaki A, Anderson GL, et al. (2009) Multivitamin use and risk of cancer and cardiovascular disease in the Women's Health Initiative cohorts. Arch Intern Med 169: 294-304.

41. Park SY, Murphy SP, Wilkens LR, Henderson BE, Kolonel LN (2011) Multivitamin use and the risk of mortality and cancer incidence: the multiethnic cohort study. Am J Epidemiol 173: 906-914.

42. Watkins ML, Erickson JD, Thun MJ, Mulinare J, Heath CW Jr (2000) Multivitamin use and mortality in a large prospective study. Am J Epidemiol 152: 149-162.

43. Mursu J, Robien K, Harnack LJ, Park K, Jacobs DR Jr (2011) Dietary supplements and mortality rate in older women: the lowa Women's Health Study. Arch Intern Med 171: 1625-1633.

44. Epstein MM, Kasperzyk JL, Andrén O, Giovannucci EL, Wolk A, et al. (2011) Dietary zinc and prostate cancer survival in a Swedish cohort. Am J Clin Nutr 93: $586-593$

45. Gonzalez A, Peters U, Lampe JW, White E (2009) Zinc intake from supplements and diet and prostate cancer. Nutr Cancer 61: 206-215.

46. Marshall DT1, Savage SJ, Garrett-Mayer E, Keane TE, Hollis BW, et al. (2012 Vitamin D3 supplementation at 4000 international units per day for one year results in a decrease of positive cores at repeat biopsy in subjects with low-risk prostate cancer under active surveillance. J Clin EndocrinolMetab. 97: 23152324.

47. Collin SM (2013) Folate and B12 in prostate cancer. Adv Clin Chem 60: 1-63.

48. de Vogel S, Meyer K, FredriksenÅ, Ulvik A, Ueland PM, et al. (2013) Serum folate and vitamin B12 concentrations in relation to prostate cancer risk--a Norwegian population-based nested case-control study of 3000 cases and 3000 controls within the JANUS cohort. Int J Epidemiol 42: 201-210.

49. Moore LE, Hung R, Karami S, Boffetta P, Berndt S, et al. (2008) Folate metabolism genes, vegetable intake and renal cancer risk in central Europe. Int J Cancer 122: 1710-1715

50. Schabath MB, Spitz MR, Lerner SP, Pillow PC, Hernandez LM, et al. (2005) Case-control analysis of dietary folate and risk of bladder cancer. Nutr Cancer 53: 144-151.

51. Albanes D, Heinonen OP, Huttunen JK, Taylor PR, Virtamo J, et al. (1995) Effects of alpha-tocopherol and beta-carotene supplements on cance incidence in the Alpha-Tocopherol Beta-Carotene Cancer Prevention Study. Am J Clin Nutr 62: 1427S-1430S.

52. Lippman SM, Klein EA, Goodman PJ, Lucia MS, Thompson IM, et al. (2009) Effect of selenium and vitamin $E$ on risk of prostate cancer and other cancers: the Selenium and Vitamin E Cancer Prevention Trial (SELECT). JAMA 301:3951.

53. Nicastro HL, Dunn BK (2013) Selenium and prostate cancer prevention: insights from the selenium and vitamin $\mathrm{E}$ cancer prevention trial (SELECT) Nutrients 5: 1122-1148.

54. Christen WG, Gaziano JM, Hennekens CH (2000) Design of Physicians' Health Study II--a randomized trial of beta-carotene, vitamins E and C, and multivitamins, in prevention of cancer, cardiovascular disease, and eye disease, and review of results of completed trials. Ann Epidemiol 10:125-134.

55. Goodman GE, Thornquist MD, Balmes J, Cullen MR, Meyskens FL Jr, et al. (2004)The Beta-Carotene and Retinol Efficacy Trial: incidence of lung cancer and cardiovascular disease mortality during 6-year follow-up after stopping beta-carotene and retinol supplements. J Natl Cancer Inst 96:1743-1750.sw

56. Ulrich CM (2007) Folate and cancer prevention: a closer look at a complex picture. Am J Clin Nutr 86: 271-273.

57. Eisenberg DM, Davis RB, Ettner SL, Appel S, Wilkey S, et al. (1998) Trends in alternative medicine use in the United States, 1990-1997: results of a follow-up national survey. JAMA 280: 1569-1575.

58. Kuroda Y, Hara Y (1999) Antimutagenic and anticarcinogenic activity of tea polyphenols. Mutat Res 436: 69-97.

59. Jung YD, Ellis LM (2001) Inhibition of tumour invasion and angiogenesis by epigallocatechingallate (EGCG), a major component of green tea. Int J Exp Pathol 82: 309-316.

60. Cao Y, Cao R (1999) Angiogenesis inhibited by drinking tea. Nature 398: 381. 
61. Goldbohm RA, Hertog MG, Brants HA, van Poppel G, van den Brandt PA (1996) Consumption of black tea and cancer risk: a prospective cohort study. J Natl Cancer Inst 88: 93-100.

62. Blot WJ, Chow WH, McLaughlin JK (1996) Tea and cancer: a review of the epidemiological evidence. Eur J Cancer Prev 5: 425-438.

63. Yang CS, Wang ZY (1993) Tea and cancer. J Natl Cancer Inst 85: 1038-1049.

64. Inoue M, Tajima K, Mizutani M, Iwata H, Iwase T, et al. (2001) Regular consumption of green tea and the risk of breast cancer recurrence: followup study from the Hospital-based Epidemiologic Research Program at Aichi Cancer Center (HERPACC), Japan. Cancer Lett 167: 175-182.

65. Muto S, Yokoi T, Gondo Y, Katsuki M, Shioyama Y, et al. (1999) Inhibition of benzo[a]pyrene-induced mutagenesis by (-)-epigallocatechingallate in the lung of rpsL transgenic mice. Carcinogenesis 20: 421-424.

66. Kuroda $Y$ (1996) Bio-antimutagenic activity of green tea catechins in cultured Chinese hamster V79 cells. Mutat Res 361: 179-186.

67. Sasaki YF, Yamada H, Shimoi K, Kator K, Kinae N (1993) Theclastogensuppressing effects of green tea, Po-lei tea and Rooibos tea in $\mathrm{CHO}$ cells and mice. Mutat Res 286: 221-232.

68. Xu M, Bailey AC, Hernaez JF, Taoka CR, Schut HA, et al. (1996) Protection by green tea, black tea, and indole-3-carbinol against 2-amino-3methylimidazo[4,5-f]quinoline-induced DNA adducts and colonic aberrant crypts in the F344 rat. Carcinogenesis 17: 1429-1434.

69. Komatsu K, Tauchi H, Yano N, Endo S, Matsuura S, et al. (1997) Inhibitory action of (-)-epigallocatechingallate on radiation-induced mouse oncogenic transformation. Cancer Lett 112: 135-139.

70. Komatsu K, Kator K, Mitsuda Y, Mine M, Okumura Y (1994) Inhibitory effects of Rooibos tea, Aspalathuslinealis, on X-ray-induced C3H10T1/2 cell transformation. Cancer Lett 77: 33-38.

71. Terao J, Piskula M, Yao Q (1994) Protective effect of epicatechin epicatechingallate, and quercetin on lipid peroxidation in phospholipid bilayers. Arch Biochem Biophys 308: 278-284.

72. Ahmad N, Cheng P, Mukhtar H (2000) Cell cycle dysregulation by green tea polyphenol epigallocatechin-3-gallate. Biochem Biophys Res Commun 275: 328-334.

73. Liang YC, Lin-Shiau SY, Chen CF, Lin JK (1999) Inhibition of cyclin-dependent kinases 2 and 4 activities as well as induction of Cdk inhibitors p21 and p27 during growth arrest of human breast carcinoma cells by (-)-epigallocatechin-3gallate. J Cell Biochem 75: 1-12.

74. Liberto M, Cobrinik D (2000) Growth factor-dependent induction of p21(CIP1) by the green tea polyphenol, epigallocatechingallate. Cancer Lett 154: 151161.

75. Smith DM, Dou QP (2001) Green tea polyphenol epigallocatechin inhibits DNA replication and consequently induces leukemia cell apoptosis. Int $\mathrm{J}$ Mol Med 7: 645-652.

76. Ahmad N, Feyes DK, Nieminen AL, Agarwal R, Mukhtar H (1997) Green tea constituent epigallocatechin-3-gallate and induction of apoptosis and cell cycle arrest in human carcinoma cells. J Natl Cancer Inst 89: 1881-1886.

77. Jankun J, Selman SH, Swiercz R, Skrzypczak-Jankun E (1997) Why drinking green tea could prevent cancer. Nature 387: 561

78. Liao S, Umekita Y, Guo J, Kokontis JM, Hiipakka RA (1995) Growth inhibition and regression of human prostate and breast tumors in athymic mice by tea epigallocatechingallate. Cancer Lett 96: 239-243.

79. Gupta S, Ahmad N, Nieminen AL, Mukhtar H (2000) Growth inhibition, cellcycle dysregulation, and induction of apoptosis by green tea constituen (-)-epigallocatechin-3-gallate in androgen-sensitive and androgen-insensitive human prostate carcinoma cells. Toxicol Appl Pharmacol 164: 82-90.

80. Islam S, Islam N, Kermode T, Johnstone B, Mukhtar H, et al. (2000) Involvement of caspase-3 in epigallocatechin-3-gallate-mediated apoptosis of human chondrosarcoma cells. Biochem Biophys Res Commun 270: 793-797.

81. Heilbrun LK, Nomura A, Stemmermann GN (1986) Black tea consumption and cancer risk: a prospective study. Br J Cancer 54: 677-683.

82. Jain MG, Hislop GT, Howe GR, Burch JD, Ghadirian P (1998) Alcohol and other beverage use and prostate cancer risk among Canadian men. Int $\mathrm{J}$ Cancer 78 : 707-711
83. Kurahashi N, Sasazuki S, Iwasaki M, Inoue M, Tsugane S; JPHC Study Group (2008) Green tea consumption and prostate cancer risk in Japanese men: a prospective study. Am J Epidemiol 167: 71-77.

84. Bettuzzi S, Brausi M, Rizzi F, Castagnetti G, Peracchia G, et al. (2006) Chemoprevention of human prostate cancer by oral administration of green tea catechins in volunteers with high-grade prostate intraepithelial neoplasia: a preliminary report from a one-year proof-of-principle study. Cancer Res 66 : 1234-1240.

85. Kolonel LN, Hankin JH, Yoshizawa CN (1987) Vitamin A and prostate cancer in elderly men: enhancement of risk. Cancer Res 47: 2982-2985.

86. Seren S, Lieberman R, Bayraktar UD, Heath E, Sahin K, et al. (2008) Lycopene in cancer prevention and treatment. Am J Ther 15: 66-81.

87. Rao AV, Agarwal S (2000) Role of antioxidant lycopene in cancer and heart disease. J Am CollNutr 19: 563-569.

88. Obermüller-Jevic UC, Olano-Martin E, Corbacho AM, Eiserich JP, van der Vliet A, et al. (2003) Lycopene inhibits the growth of normal human prostate epithelial cells in vitro. J Nutr 133: 3356-3360.

89. Ilic D, Misso M (2012) Lycopene for the prevention and treatment of benign prostatic hyperplasia and prostate cancer: a systematic review. Maturitas 72 : 269-276.

90. Chen J, Song Y, Zhang L (2013) Lycopene/tomato consumption and the risk of prostate cancer: a systematic review and meta-analysis of prospective studies. J Nutr Sci Vitaminol (Tokyo) 59: 213-223.

91. Marks LS, Hess DL, Dorey FJ, Luz Macairan M, Cruz Santos PB, et al. (2001) Tissue effects of saw palmetto and finasteride: use of biopsy cores for in situ quantification of prostatic androgens. Urology 57: 999-1005.

92. Bonnar-Pizzorno RM, Littman AJ, Kestin M, White E (2006) Saw palmetto supplement use and prostate cancer risk. Nutr Cancer 55: 21-27.

93. Longtin R (2003) The pomegranate: nature's power fruit? J Natl Cancer Inst 95: $346-348$

94. Schubert SY, Lansky EP, Neeman I (1999) Antioxidant and eicosanoid enzyme inhibition properties of pomegranate seed oil and fermented juice flavonoids. $J$ Ethnopharmacol 66: 11-17

95. Gil MI, Tomás-Barberán FA, Hess-Pierce B, Holcroft DM, Kader AA (2000) Antioxidant activity of pomegranate juice and its relationship with phenolic composition and processing. J Agric Food Chem 48: 4581-4589.

96. Noda Y, Kaneyuki T, Mori A, Packer L (2002) Antioxidant activities of pomegranate fruit extract and its anthocyanidins: delphinidin, cyanidin, and pelargonidin. J Agric Food Chem 50: 166-171.

97. Malik A, Afaq F, Sarfaraz S, Adhami VM, Syed DN, et al. (2005) Pomegranate fruit juice for chemoprevention and chemotherapy of prostate cancer. ProcNatlAcad Sci U S A 102: 14813-14818.

98. Sartippour MR, Seeram NP, Rao JY, Moro A, Harris DM, et al. (2008) Ellagitannin-rich pomegranate extract inhibits angiogenesis in prostate cancer in vitro and in vivo. Int $\mathrm{J}$ Oncol 32: 475-480.

99. Pantuck AJ, Leppert JT, Zomorodian N, Aronson W, Hong J, et al. (2006) Phase II study of pomegranate juice for men with rising prostate-specific antigen following surgery or radiation for prostate cancer. Clin Cancer Res 12: 40184026 .

100. Shimoi K, Saka N, Kaji K, Nozawa R, Kinae N (2000) Metabolic fate of luteolin and its functional activity at focal site. Biofactors 12: 181-186.

101. Chiu FL, Lin JK (2008) Downregulation of androgen receptor expression by luteolin causes inhibition of cell proliferation and induction of apoptosis in human prostate cancer cells and xenografts. Prostate 68: 61-71.

102. Atmaca A, Kleerekoper M, Bayraktar M, Kucuk O (2008) Soy isoflavones in the management of postmenopausal osteoporosis. Menopause 15: 748-757.

103. Hebert JR, Hurley TG, Olendzki BC, Teas J, Ma Y, et al. (1998) Nutritional and socioeconomic factors in relation to prostate cancer mortality: a cross-national study. J Natl Cancer Inst 90: 1637-1647.

104.Lakshman M, Xu L, Ananthanarayanan V, Cooper J, Takimoto $\mathrm{CH}$, et al. (2008) Dietary genistein inhibits metastasis of human prostate cancer in mice. Cancer Res 68: 2024-2032.

105. Wang Y, Raffoul JJ, Che M, Doerge DR, Joiner MC, et al. (2006) Prostate 
cancer treatment is enhanced by genistein in vitro and in vivo in a syngeneic orthotopic tumor model. Radiat Res 166: 73-80.

106. Hussain M, Banerjee M, Sarkar FH, Djuric Z, Pollak MN, et al. (2003) Soy isoflavones in the treatment of prostate cancer. Nutr Cancer 47: 111-117.

107. Pendleton JM, Tan WW, Anai S, Chang M, Hou W, et al. (2008) Phase II trial of isoflavone in prostate-specific antigen recurrent prostate cancer after previous local therapy. BMC Cancer 8: 132.

108. Djuric Z, Chen G, Doerge DR, Heilbrun LK, Kucuk O (2001) Effect of soy isoflavone supplementation on markers of oxidative stress in men and women. Cancer Lett 172: 1-6.

109. Davis JN, Kucuk O, Djuric Z, Sarkar FH (2001) Soy isoflavone supplementation in healthy men prevents NF-kappa B activation by TNF-alpha in blood lymphocytes. Free Radic Biol Med 30: 1293-1302.

110. Davis JN, Kucuk O, Sarkar FH (1999) Genistein inhibits NF-kappa B activation in prostate cancer cells. Nutr Cancer 35: 167-174.

111. Blay M, Espinel AE, Delgado MA, Baiges I, Bladé C, et al. (2010) Isoflavone effect on gene expression profile and biomarkers of inflammation. J Pharm Biomed Anal 51: 382-390.

112. Vaishampayan U, Hussain M, Banerjee M, Seren S, Sarkar FH, et al. (2007) Lycopene and soy isoflavones in the treatment of prostate cancer. Nutr Cancer 59: $1-7$.

113. Thompson IM, Goodman PJ, Tangen CM, Lucia MS, Miller GJ, et al. (2003) The influence of finasteride on the development of prostate cancer. $N$ Engl $J$ Med 349: 215-224.

114. Andriole GL, Bostwick DG, Brawley OW, Gomella LG, Marberger M, et al (2010) Effect of dutasteride on the risk of prostate cancer. N Engl J Med 362 1192-1202.

115. Grubb RL, Andriole GL, Somerville MC, Mahoney C, Manyak MJ, et al. (2013) The REDUCE Follow-Up Study: low rate of new prostate cancer diagnoses observed during a 2-year, observational, followup study of men who participated in the REDUCE trial. J Urol 189: 871-877.

116. Goldstein JL, Brown MS (1990) Regulation of the mevalonate pathway. Nature 343: 425-430

117. (1998) Prevention of cardiovascular events and death with pravastatin in patients with coronary heart disease and a broad range of initial cholestero levels. The Long-Term Intervention with Pravastatin in Ischaemic Disease (LIPID) Study Group. N Engl J Med 339: 1349-1357.

118. Vaczek D (2005) Top 200 prescription drugs of 2004. Pharmacy Times.

119. Jakobisiak M, Golab J (2003) Potential antitumor effects of statins (Review). Int J Oncol 23: 1055-1069.

120. Platz EA, Leitzmann MF, Visvanathan K, Rimm EB, Stampfer MJ, et al. (2006) Statin drugs and risk of advanced prostate cancer. J Natl Cancer Inst 98: 1819-1825.

121. Edwards PA, Ericsson J (1999) Sterols and isoprenoids: signaling molecules derived from the cholesterol biosynthetic pathway. Annu Rev Biochem 68: 157-185.

122. Graaf MR, Richel DJ, van Noorden CJ, Guchelaar HJ (2004) Effects of statins and farnesyltransferase inhibitors on the development and progression of cancer. Cancer Treat Rev 30: 609-641.

123. Chan KK, Oza AM, Siu LL (2003) The statins as anticancer agents. Clin Cancer Res 9: 10-19.

124. Boudreau DM, Yu O, Johnson J (2010) Statin use and cancer risk: a comprehensive review. Expert Opin Drug Saf 9: 603-621.

125.Zhang XL, Geng J, Zhang XP, Peng B, Che JP, et al. (2013) Statin use and risk of bladder cancer: a meta-analysis. Cancer Causes Control 24: 769-776.

126. Zhang XL, Liu M, Qian J, Zheng JH, Zhang XP, et al. (2014) Statin use and risk of kidney cancer: a meta-analysis of observational studies and randomized trials. Br J Clin Pharmacol 77: 458-465.

127. Alimova IN, Liu B, Fan Z, Edgerton SM, Dillon T, et al. (2009) Metformin inhibits breast cancer cell growth, colony formation and induces cell cycle arrest in vitro. Cell Cycle 8: 909-915.

128. Bowker SL, Majumdar SR, Veugelers P, Johnson JA (2006)Increased cancer- related mortality for patients with type 2 diabetes who use sulfonylureas or insulin. Diabetes Care 29: 254-258.

129.Patel T, Hruby G, Badani K, Abate-Shen C, McKiernan JM (2010) Clinica outcomes after radical prostatectomy in diabetic patients treated with metformin. Urology 76: 1240-1244.

130. Hirsch HA, lliopoulos D, Tsichlis PN, Struhl K (2009) Metformin selectively targets cancer stem cells, and acts together with chemotherapy to block tumor growth and prolong remission. Cancer Res 69: 7507-7511.

131.Decensi A, Puntoni M, Goodwin P, Cazzaniga M, Gennari A, et al. (2010) Metformin and cancer risk in diabetic patients: a systematic review and metaanalysis. Cancer Prev Res (Phila) 3: 1451-1461.

132. Peairs KS, Barone BB, Snyder CF, Yeh HC, Stein KB, et al. (2011) Diabetes mellitus and breast cancer outcomes: a systematic review and meta-analysis. J Clin Oncol 29: 40-46.

133. Margel D, Urbach D, Lipscombe LL, Bell CM, Kulkarni G, et al. (2013) Association between metformin use and risk of prostate cancer and its grade. J Natl Cancer Inst 105: 1123-1131.

134.Sfanos KS, De Marzo AM (2012) Prostate cancer and inflammation: the evidence. Histopathology 60: 199-215.

135. Gupta S, Srivastava M, Ahmad N, Bostwick DG, Mukhtar H (2000) Overexpression of cyclooxygenase-2 in human prostate adenocarcinoma. Prostate 42: 73-78.

136. Narayanan BA, Narayanan NK, Pittman B, Reddy BS (2004) Regression of mouse prostatic intraepithelial neoplasia by nonsteroidal anti-inflammatory drugs in the transgenic adenocarcinoma mouse prostate model. Clin Cancer Res 10: 7727-7737.

137. Mahmud SM, Franco EL, Aprikian AG (2010) Use of nonsteroidal antiinflammatory drugs and prostate cancer risk: a meta-analysis. Int $\mathrm{J}$ Cancer 127: 1680-1691.

138. Barratt A, Irwig L, Glasziou P, Cumming RG, Raffle A, et al. (1999) Users' guides to the medical literature: XVII. How to use guidelines and recommendations about screening. Evidence-Based Medicine Working Group. JAMA 281: 20292034.

139. Chow WH, Devesa SS, Warren JL, Fraumeni JF Jr (1999) Rising incidence of renal cell cancer in the United States. JAMA 281: 1628-1631.

140. Hock LM, Lynch J, Balaji KC (2002)Increasing incidence of all stages of kidney cancer in the last 2 decades in the United States: an analysis of surveillance epidemiology and end results program data. J Urol 167: 57-60.

141. Ries LAG, Eisner MP, Kosary CL, HankeyBF, Miller BA, Clegg L, et al. (2005) SEER Cancer Statistics Review, 1975-2002. National Cancer Institute.

142. Vaishampayan UN, Do H, Hussain M, Schwartz K (2003) Racial disparity in incidence patterns and outcome of kidney cancer. Urology 62: 1012-1017.

143. Figlin RA (1999) Renal cell carcinoma: management of advanced disease. J Urol 161: 381-386.

144. Hollenbeck BK, Taub DA, Miller DC, Dunn RL, Wei JT (2006) National utilization trends of partial nephrectomy for renal cell carcinoma: a case of underutilization? Urology 67: 254-259.

145. Ilic D, Misso ML (2011) Screening for testicular cancer. Cochrane Database SystRev: CD007853.

146. Moyer VA (2011) Screening for Testicular Cancer: U.S. Preventive Services Task Force Reaffirmation Recommendation Statement. Ann Intern Med 154 483-486.

147. Albers P, Albrecht W, Algaba F, Bokemeyer C, Cohn-Cedermark G, et al. (2012) Guidelines on testicular cancer.European Association of Urology.

148. Grossfeld GD, Litwin MS, Wolf JS Jr, Hricak H, Shuler CL, et al. (2001) Evaluation of asymptomatic microscopic hematuria in adults: the American Urological Association best practice policy--part II: patient evaluation, cytology, voided markers, imaging, cystoscopy, nephrology evaluation, and follow-up. Urology 57:604-610.

149. Giannopoulos A, Manousakas T, Gounari A, Constantinides C, ChoremiPapadopoulou $\mathrm{H}$, et al. (2001) Comparative evaluation of the diagnostic performance of the BTA stat test, NMP22 and urinary bladder cancer antigen for primary and recurrent bladder tumors. J Urol 166: 470-475. 
Citation: Fouad A, Peltier A (2014) Prevention and Early Detection of Urologic Cancers: A Mini-Review. Med chem S1: 006. doi:10.4172/2161-0444. S1-006

150. Simon MA, Lokeshwar VB, Soloway MS (2003) Current bladder cancer tests: unnecessary or beneficial? Crit Rev Oncol Hematol 47: 91-107.

151.van der Poel HG, Debruyne FM (2001) Can biological markers replace cystoscopy? An update. CurrOpinUrol 11: 503-509.

152. Moyer VA; US. Preventive Services Task Force. (2011) Screening for bladder cancer: U.S. Preventive Services Task Force recommendation statement. Ann Intern Med 155: 246-251.

153. Schröder FH, Hugosson J, Roobol MJ, Tammela TL, Ciatto S, et al. (2009) Screening and prostate-cancer mortality in a randomized European study. N Engl J Med 360: 1320-1328.

154. Hugosson J, Carlsson S, Aus G, Bergdahl S, Khatami A, et al. (2010) Mortality results from the Göteborg randomised population-based prostate-cancer screening trial. Lancet Oncol 11: 725-732.

155. Roobol MJ, Kranse R, Bangma CH, van Leenders AG, Blijenberg BG, et al. (2013)Screening for prostate cancer: results of the Rotterdam section of the European randomized study of screening for prostate cancer. Eur Urol 64 530-539.
156. Kilpeläinen TP, Tammela TL, Malila N, Hakama M, Santti H, et al. (2013) Prostate cancer mortality in the Finnish randomized screening trial. J Nat Cancer Inst 105: 719-725.

157. Andriole GL, Crawford ED, Grubb RL 3rd, Buys SS, Chia D, et al. (2009) Mortality results from a randomized prostate-cancer screening trial. $\mathrm{N}$ Engl $\mathrm{J}$ Med 360: 1310-1319.

158. Moyer VA (2012)Screening for prostate cancer: U.S. Preventive Services Task Force recommendation statement. Ann Intern Med 157:120-134.

159. American Cancer Society Guidelines for the Early Detection of Cancer. American Cancer Society.

160. Heidenreich A, Bastian PJ, Bellmunt J, Bolla M, Joniau S, et al. (2014) EAU guidelines on prostate cancer. part 1: screening, diagnosis, and local treatment with curative intent-update 2013. Eur Urol 65: 124-137.

161.Greene KL, Albertsen PC, Babaian RJ, Carter HB, Gann PH, et al. (2013) Prostate specific antigen best practice statement: 2009 update. J Urol 189: S2-2S11. 